\title{
Perbandingan Produktivitas, Biaya Pokok Produksi dan Pendapatan Usahatani Padi Organik dan Nonorganik di Kabupaten Pringsewu
}

\section{Comparison of Productivity, Cost of Production and Income of The Organic and Non-organic Rice Farming in Pringsewu Regency}

\author{
Sari Nurhidayati ${ }^{1 *}$, Agus Hudoyo ${ }^{2}$, dan Dwi Haryono ${ }^{3}$ \\ ${ }^{1}$ Magister Agribisnis / Universitas Lampung \\ ${ }^{2,3}$ Agribisnis/ Universitas Lampung \\ *E-mail : sari.nurhidayati02@gmail.com
}

\begin{abstract}
Pringsewu Regency has the highest organic rice production area in Lampung Province, but organic rice productivity is low. Farmers have not fully carried out organic rice farming. Most farmers are farming non-organic rice. This is because farmers think that low productivity of organic rice leads to low income of rice farmers. This study aims to analyze the differences in productivity, costs, and income of organic and non-organic rice farming in Pringsewu Regency. Data were collected in two sub-districts which are organic and non-organic rice farmers in Pringsewu District, namely Pringsewu and Pardasuka districts, in August 2020 by observing the last 3 planting seasons namely MH 2019/2020, MK 2019 and MH 218/2019. The number of respondents were 18 people. Therefore the total observations were 108. The data were analyzed using multiple regression analysis models with the dependent variable, namely productivity, costs and income. The independent variables are organic rice, location and planting season. The results showed that the average productivity of organic rice farming was 0.97ton/ha lower than that of nonorganic rice. The average cost of organic rice farming was Rp. 1.593/kg higher than non-organic rice. The average revenue of organic rice farming was Rp. 7.12 million/ha, higher than non-organic rice.
\end{abstract}

Keywords: Organic-Nonorganic Rice Farming, Productivity, Cost, Income

Disubmit : 8 Maret $2021 \quad$ Diterima: 29 April $2021 \quad$ Disetujui : 29 Oktober 2021

\section{PENDAHULUAN}

Sektor pertanian merupakan sektor terpenting dalam pembangunan perekonomian di Indonesia khususnya sektor tanaman pangan yang menghasilkan komoditas padi. Padi merupakan bahan pangan yang harus selalu terpenuhi ketersediaan dari kuantitas, kualitas dan segi harga yang terjangkau disetiap lapisan masyarakat. Kondisi tersebut menyebabkan komoditas padi mempunyai pengaruh yang cukup besar terhadap kestabilan perekonomian Nasional. Padi mempunyai peranan yang strategis dalam ketahanan 
pangan, ketahanan ekonomi dan stabilitas politik nasional. Program pembangunan di sektor pertanian yang menjadi salah satu prioritas pemerintah yaitu menjaga kelestarian lingkungan. Pertanian organik merupakan program budidaya penting dari sekian banyak cara yang dapat mendukung pelestarian lingkungan. Sistem pertanian organik didasarkan pada standar produksi yang spesifik dan teliti dengan tujuan untuk menciptakan agroekosistem yang optimal dan lestari berkelanjutan baik secara sosial, ekologi, maupun ekonomi dan etika (Statistik, 2016). Pertanian organik merupakan cara bercocok tanam yang ramah lingkungan. Pertanian organik dibandingkan dengan konvensional adalah penggunaan pupuk dan pestisida berbahan organik yang aman.

(Maryowani, 2012) menjelaskan bahwa pertanian organik di Indonesia mengalami perkembangan tetapi belum sepenuhnya memasyarakat, baik oleh petani sendiri maupun oleh pemerintah yang telah mencanangkan program kembali ke organik (go organic) Tahun 2010. Walaupun program kembali ke pertanian organik tidak berjalan seperti apa yang diharapkan, Indonesia masih mempunyai peluang untuk mengembangkan pertanian organik khususnya padi organik dengan potensi yang dimilikinya

Pertanian organik yang diusahakan oleh pemerintah untuk pertanian berkelanjutan masih belum banyak diterapkan oleh petani. Hal ini dilatarbelakangi karena petani berasumsi bahwa pertanian organik akan merugikan petani karena produktivitas yang rendah. (Heryanto, Mahra, Sukayat and Supyandi, 2016) menjelaskan produktivitas pertanian organik pada tahap awal akan mengalami penurunan namun akan mengalami kenaikan seiring waktu, sedangkan pertanian konvensional pada awal memiliki produktivitas tinggi namun akan mengalami penurunan karena unsur hara yang menjadi miskin. Permasalahan pertanian organik bukan hanya produktivitas yang rendah, tetapi dari besarnya biaya yang dikeluarkan, hal tersebut dikarenakan sarana produksi yang digunakan kedua jenis usahatani berbeda sehingga akan mempengaruhi besarnya biaya yang dikeluarkan.

Berdasarkan hal tersebut, maka penting bagi petani untuk mengetahui perbandingan produktivitas, biaya dan pendapatan usahatani padi organik dan nonorganik secara tepat sebagai bahan evaluasi dan pengembangan pertanian organik ke depannya. Tujuan penelitian ini menganalisis perbandingan produktivitas usahatani padi organik dan nonorganik di Kabupaten Pringsewu dan menganalisis perbandingan struktur biaya usahatani padi organik dan nonorganik di Kabupaten Pringsewu serta menganalisis perbandingan pendapatan usahatani padi organik dan nonorganik di Kabupaten Pringsewu.

\section{METODE PENELITIAN}

Penelitian dilakukan dengan metode sensus pada petani padi organik Kecamatan Pringsewu dan Kecamatan Pardasuka, Kabupaten Pringsewu. Lokasi tersebut dipilih secara sengaja (purposive) dengan pertimbangan bahwa dua kecamatan tersebut memiliki sertifikat organic (Sutarni et al., 2019). Petani padi nonorganik merupakan petani yang juga merupakan petani organik dengan lahan yang berbeda. Penelitian dilakukan pada bulan Agustus 2020. Jumlah responden yang digunakan adalah 18 orang yang berasal dari dua kecamatan, yaitu Kecamatan Pringsewu dan Kecamatan Pardasuka. Kecamatan Pringsewu sebagai lokasi 1 dan Kecamatan Pardasuka sebagai lokasi 2. Data yang diambil dalam penelitian ini yaitu data tiga musim tanam (MT) terakhir yaitu MH 2019/2020, MK2019 dan MH 2018/2019. Penelitian ini menggunakan 18 responden dengan 108 observasi (sampel) yang merupakan petani organik di Kabupaten Pringsewu. Menurut (Cohen, L., Moarion, L. dan Marrioson, 2007), semakin besar sampel yang diambil dalam suatu populasi maka hasil yang diperoleh akan semakin baik, namun sampel yang akan digunakan memiliki batas minimal yang diambil yaitu sebesar 30 sampel. 
Data dianalisis dengan menggunakan model regresi berganda dengan produktivitas, biaya pokok produksi dan pendapatan merupakan variabel terikat (Y) dan empat variabel boneka merupakan variabel bebas $(\mathrm{X})$ atau dummy. Penggunaan variabel dummy sebagai variabel bebas digunakan untuk membedakan produktivitas, biaya pokok produksi dan pendapatan antara usahatani padi organik dan nonorganik.

Menurut (Torchim, 2020) pada desain penelitian variabel dummy sering digunakan untuk membedakan kelompok perlakuan yang berbeda. Dalam kasus yang paling sederhana penggunaan variabel dummy 0,1 di mana seseorang diberi perlakuan 0 jika berada dalam kelompok kontrol atau 1 jika mereka berada pada kelompok perlakuan. Variabel tiruan berguna karena memungkinkan kita menggunakan persamaan regresi tunggal untuk mewakili banyak kelompok. Artinya, kita tidak perlu menulis model persamaan terpisah untuk setiap subkelompok. Variabel dummy bertindak seperti 'sakelar' yang mengaktifkan dan menonaktifkan berbagai parameter dalam sebuah persamaan. Metode estimasi yang digunakan adalah Ordinary Least Square (OLS) dengan menggunakan Excel. Selain itu, dapat juga dilakukan dengan menggunakan SPSS dan Eviews, namun dalam penelitian ini menggunakan Excel. Secara matematis dapat dituliskan dengan rumus sebagai berikut:

$Y_{1 i}=\hat{a}_{0}+\hat{a}_{1} D_{1 i}+\hat{a}_{2} D_{2 i}+\hat{a}_{3} D_{3 i}+\hat{a}_{4} D_{4 i}+e_{1 i}$

$Y_{2 i}=\hat{b}_{0}+\widehat{b}_{1} D_{1 i}+\widehat{b}_{2} D_{2 i}+\widehat{b}_{3} D_{3 i}+\widehat{b}_{4} D_{4 i}+e_{2 i}$

$Y_{3 i}=\hat{c}_{0}+\hat{c}_{1} D_{1 i}+\hat{c}_{2} D_{2 i}+\hat{c}_{3} D_{3 i}+\hat{c}_{4} D_{4 i}+e_{3 i}$

Keterangan:

$\mathrm{Y}_{1}=$ Produktivitas (ton/ha)

$\mathrm{Y}_{2}=$ Biaya pokok produksi $(\mathrm{Rp} / \mathrm{kg})$

$\mathrm{Y}_{3} \quad=$ Pendapatan $(\mathrm{Rp} \mathrm{juta/ha})$

$\hat{a}, \hat{b}, \hat{c}, \quad=$ Koefisien penduga

$\hat{a}_{0}, \widehat{b}_{0}, \hat{c}_{0}=$ Intersep

$\mathrm{i}=$ Observasi $1,2,3, \ldots, 108$

$\mathrm{D}_{1} \quad=$ Budidaya padi organik $\mathrm{D}_{1}=1$; Organik, $\mathrm{D}_{1}=0$; Nonorganik

$\mathrm{D}_{2}$ dan $\mathrm{D}_{3}=$ Musim Tanam (MT)

$\mathrm{D}_{2}=1 ; \mathrm{D}_{3}=0 ; \mathrm{MH} 2019 / 2020$

$\mathrm{D}_{2}=0 ; \mathrm{D}_{3}=1 ;$ MK 2019

$\mathrm{D}_{2}=0 ; \mathrm{D}_{3}=0 ; \mathrm{MH} 2018 / 2019$

$\mathrm{D}_{4} \quad=$ Lokasi

$\mathrm{D}_{4}=1 ;$ Lokasi $1, \mathrm{D}_{4}=0 ;$ Lokasi 2

$\mathrm{e}_{1}, \mathrm{e}_{2}, \mathrm{e}_{3}=$ Galat

\section{HASIL DAN PEMBAHASAN}

\section{Perbandingan produktivitas usahatani padi organik dan nonorganik di Kabupaten Pringsewu}

Hasil dari rata-rata, minimum, dan maksimum untuk produktivitas, biaya pokok, dan pendapatan usahatani padi dapat dilihat pada Tabel 1. Berdasarkan Tabel 1, dapat dijelaskan bahwa terdapat perbedaan yang nyata hasil produksi, biaya pokok dan pendapatan antara petani padi organik dan nonorganik. Terlihat bahwa produktivitas yang dihasilkan oleh petani organik lebih rendah dari pada petani nonorganik dan biaya pokok produksi yang dikeluarkan lebih tinggi petani organik. Namun jika dilihat, pendapatan petani organik lebih tinggi dibandingkan dengan petani nonorganik.

Tabel 1. Data hasil observasi produktivitas, biaya pokok dan pendapatan usahatani padi organik dan nonorganik. 


\begin{tabular}{lcccccc}
\hline \multirow{2}{*}{ Keterangan } & \multicolumn{3}{c}{ Organik } & \multicolumn{3}{c}{ Nonorganik } \\
\cline { 2 - 7 } & Rata-Rata & Minimum & Maksimum & Rata-Rata & Minimum & Maksimum \\
\hline Produktivitas (ton/ha) & 4,34 & 2,39 & 5,54 & 5,31 & 3,85 & 5,98 \\
Biaya Pokok (Rp/Kg) & 4.937 & 3.332 & 9.262 & 3.344 & 2.284 & 4.362 \\
Pendapatan (Rp Juta/ha) & 18,36 & 1,04 & 28,89 & 11,23 & 5,19 & 17,79 \\
\hline
\end{tabular}

\section{a. Estimasi Model Empiris dan Uji Hipotesis}

\section{1) Produktivitas}

Hasil analisis perbedaan produktivitas (ton/ha ) usahatani padi organik dan padi nonorganik dapat dilihat pada Tabel 2. Pada Tabel 2, terdapat dua analisis model regresi. Variabel bebas yang digunakan merupakan variabel yang sesuai dengan metodologi dan variabel selain variabel organik merupakan variabel kontrol. Model 1 dapat dilihat bahwa ada salah satu variabel bebas yang tidak signifikan terhadap produktivitas padi yaitu variabel musim tanam.

Tabel 2. Data hasil observasi produktivitas, biaya pokok dan pendapatan usahatani padi organik dan nonorganik

\begin{tabular}{|c|c|c|c|c|c|c|c|}
\hline \multirow{2}{*}{ Variabel bebas } & \multirow{2}{*}{ Uraian } & \multicolumn{3}{|c|}{ Model 1} & \multicolumn{3}{|c|}{ Model 2} \\
\hline & & Koefisien & P-value & & Koefisien & P-value & \\
\hline Intersep & & 5,59 & $2,46 \mathrm{E}-65$ & $*$ & 5,58 & $1,28 \mathrm{E}-76$ & $*$ \\
\hline D1 & Organik & $-0,97$ & $1,39 \mathrm{E}-12$ & $*$ & $-0,97$ & $1,15 \mathrm{E}-12$ & $*$ \\
\hline D2 (kontrol) & MT & 0,08 & $5,77 \mathrm{E}-01$ & & - & & \\
\hline D3(kontrol) & MT & $-0,10$ & $4,93 \mathrm{E}-01$ & & - & & \\
\hline D4(kontrol) & Lokasi & $-0,50$ & $7,88 \mathrm{E}-05$ & $*$ & $-0,50$ & $7,54 \mathrm{E}-05$ & $*$ \\
\hline $\mathrm{R}^{2}$ & & 0,4479 & & & 0,4395 & & \\
\hline Adj. $R^{2}$ & & 0,4264 & & & 0,4288 & & \\
\hline Ftest & & 20,8887 & $1,25 \mathrm{E}-12$ & $*$ & 41,1657 & $6,32 \mathrm{E}-14$ & $*$ \\
\hline Observasi & & 108 & & & 108 & & \\
\hline
\end{tabular}

Keterangan:

* Signifikan

Sumber : Data Primer, 2020 (data diolah)

Pada Tabel 2, model 2 menunjukkan bahwa R2 adalah sebesar 0,4395 yang artinya bahwa 43,95\% produktivitas padi dapat dijelaskan oleh variabel padi organik dan lokasi, sedangkan sisanya sebesar $56,05 \%$ dijelaskan oleh variabel lain yang tidak dimasukkan ke dalam model. F test pada hasil regresi produktivitas padi memiliki taraf nyata $\alpha$ sebesar $1 \%$. Berdasarkan hasil uji t diperoleh bahwa variabel padi organik dan lokasi signifikan terhadap produktivitas padi. Produktivitas padi organik lebih rendah dibandingkan produktivitas padi nonorganik dengan taraf nyata $\alpha$ sebesar $1 \%$. Tanpa membedakan lokasi rata-rata produktivitas padi organik secara statistik $(\alpha=1 \%)$ lebih rendah yaitu sebesar 0,97 ton/ha dibandingkan dengan produktivitas padi nonorganik. Model empiris dan hasil pengedropan variabel bebas dapat dilihat pada Tabel 2 .

Tabel 2, model 1 adalah hasil pertama yang diperoleh dengan menggunakan variabel bebas yaitu padi organik, musim tanam dan lokasi. Kemudian model 2 adalah hasil regresi yang diperoleh setelah dilakukan pengedropan pada variabel musim tanam. Berdasarkan Tabel 2 pada model 2 maka diperoleh model persamaan perbandingan produktivitas padi organik dan padi nonorganik sebagai berikut:

$\mathrm{Y}^{\wedge} 1=5,58-0,97 \mathrm{D} 1-0,50 \mathrm{D} 4$

Keterangan:

$\mathrm{Y}^{\wedge}=$ Produktivitas (ton/ha)

Berdasarkan persamaan yang telah diperoleh selanjutnya variabel bebas yang digunakan kemudian dimasukan ke dalam model. Rata-rata produktivitas yang diperoleh dapat dilihat pada Tabel 3. 
Tabel 3. Rata-rata produktivitas padi (ton/ha) di Kabupaten Pringsewu

\begin{tabular}{llll}
\hline Lokasi & Organik & Nonorganik & Rata-Rata \\
\hline Kec. Pringsewu & 4,12 & 5,09 & $\mathbf{4 , 6 0}$ \\
Kec. Pardasuka & 4,62 & 5,58 & $\mathbf{5 , 1 0}$ \\
\hline Rata-Rata & $\mathbf{4 , 3 7}$ & $\mathbf{5 , 3 4}$ & $\mathbf{4 , 8 5}$ \\
\hline
\end{tabular}

Tabel 3 menunjukkan bahwa produktivitas padi organik lebih rendah dibandingkan produktivitas padi nonorganik. Rata-rata produktivitas padi organik yaitu sebesar 4,37 ton/ha. Rata -rata produktivitas padi nonorganik yaitu 5,34 ton/ha. Persentase perbandingan produktivitas padi organik yaitu sebesar $18,16 \%$. Hal ini menunjukkan bahwa budidaya padi organik memiliki produksi yang lebih rendah dibandingkan produksi padi nonorganik. Hal ini sejalan dengan penelitian (Pratama, D.I.A, Setiawan, B.M, Prasetyo, 2018) yang menyatakan bahwa hasil produksi usahatani padi semi organik lebih rendah dibandingkan produksi pada usahatani padi nonorganik. Sejalan dengan penelitian (Hadi, M., Dipokusumo, B., dan Zubair, 2019) yang menyatakan bahwa rata-rata produksi padi nonorganik lebih tinggi dibandingkan padi organik.

Produksi yang rendah terjadi karena pada proses budidaya padi organik petani sama sekali tidak menggunakan pupuk anorganik dan insektisida kimia lainnya. Sehingga produksi yang turun disebabkan karena sebelumnya tanah telah terbiasa menerima pupuk anorganik yang dapat menyediakan unsur-unsur yang diperlukan oleh tanaman dan dapat meningkatkan produksi padi serta pestisida kimia yang mampu dengan cepat mengendalikan hama dan penyakit tanaman.

Pada budidaya padi organik semua input yang digunakan diperoleh dari apa yang telah tersedia dialam, seperti pupuk yang dibuat oleh petani dari dedauan dan kotoran hewan begitupun dengan pestisida nabati yang petani gunakan untuk mengendalikan hama dan penyakit tanaman. Termasuk dengan air yang digunakan untuk mengairi sawah petani padi organik disaring terlebih dahulu dengan tanaman eceng gondok biasanya disebut dengan box filter. Luasan box filter disesuaikan dengan luasan area tanam untuk padi organik untuk mencukupi kebutuhan air untuk melakukan budidaya padi organik agar air yang digunakan untuk melakukan budidaya padi organik lebih steril dari bahan-bahan kimia.

\section{Analisis perbandingan struktur biaya usahatani padi organik dan nonorganik di Kabupaten Pringsewu.}

Hasil dari perbandingan biaya pokok $(\mathrm{Rp} / \mathrm{Kg})$ padi organik dan padi nonorganik dapat dilihat pada Tabel 4. Tabel 4, terdapat dua analisis model regresi. Variabel bebas yang digunakan merupakan variabel yang sesuai dengan metodelogi dan variabel selain variabel organik merupakan variabel kontrol. Pada model 1 dapat dilihat bahwa ada salah satu variabel bebas yang tidak signifikan terhadap biaya pokok padi yaitu variabel musim tanam, karena terdapat variabel bebas yang tidak signifikan, kemudian dilakukan perubahan pengelompokkan dummy untuk variabel musim tanam. Perubahan yang dilakukan yaitu variabel musim tanam yang tadinya dibedakan berdasarkan musim tanam dan tahun musim tanam kemudian diubah menjadi hanya berdasarkan jenis musim tanam sehingga terdapat variabel bebas baru yaitu D5.

Perubahan ini dilakukan karena hasil analisis yang dilakukan untuk model 1 variabel musim tanam terdapat hasil yang tidak signifikan. Setelah dilakukan perubahan pada musim tanam maka diperoleh hasil seperti model 2. Selanjutnya hasil pada model 2 ini yang akan digunakan untuk analisis. Perubahan pengelompokkan dummy dapat dilakukan jika telah memenuhi kriteria yang 
telah ditentukan, yaitu terdapat variabel bebas yang tidak signifikan terhadap variabel terikat dan terjadi kenaikan nilai adj R2 pada hasil analisis model selanjutnya.

Tabel 4. Model empiris analisis perbedaan biaya pokok produksi padi organik dengan padi nonorganik $(\mathrm{Rp} / \mathrm{kg})$

\begin{tabular}{llrrrrrr}
\hline \multicolumn{1}{c}{$\begin{array}{c}\text { Variabel } \\
\text { bebas }\end{array}$} & \multirow{2}{*}{ Uraian } & \multicolumn{2}{c}{ Model 1 } & \multicolumn{3}{c}{ Model 2 } \\
\cline { 3 - 8 } & & Koefisien & P-value & \multicolumn{2}{c}{ Koefisien } & P-value & \\
\hline Intersep & & 2.841 & $2,29 \mathrm{E}-24$ & $*$ & 3.149 & $1,19 \mathrm{E}-27$ & $*$ \\
D1 & Organik & 1.593 & $8,34 \mathrm{E}-14$ & $*$ & 1.593 & $6,51 \mathrm{E}-14$ & $*$ \\
D2 (kontrol) & MT & -83 & $7,16 \mathrm{E}-01$ & - & & \\
D3 (kontrol) & MT & 308 & $1,76 \mathrm{E}-01$ & - & & \\
D5 (kontrol) & MT & - & & -349 & $7,62 \mathrm{E}-02$ & $*$ \\
D4 (kontrol) & Lokasi & 770 & $6,97 \mathrm{E}-05$ & $*$ & 770 & $6,49 \mathrm{E}-05$ & $*$ \\
\hline $\mathrm{R}^{2}$ & & 0,4795 & & & 0,4788 & & \\
Adj. R $\mathrm{R}^{2}$ & & 0,4592 & & & 0,4638 & & \\
Ftest & 23,7183 & $6,41 \mathrm{E}-14$ & $*$ & 31,8454 & $1,10 \mathrm{E}-14$ & $*$ \\
Observasi & & 108 & & & 108 & & \\
\hline
\end{tabular}

Keterangan:

*: Signifikan

D5=1: Musim Hujan dan D5=0: Musim Kemarau

Tabel 4, diperoleh $\mathrm{R}^{2}$ pada model 2 adalah sebesar 0,4788 yang artinya bahwa 47,88\% biaya pokok produksi padi dapat dijelaskan oleh variabel padi organik, musim tanam dan lokasi, sedangkan sisanya sebesar 52,12\% dijelaskan oleh variabel lain yang tidak dimasukan ke dalam model. F-hitung pada hasil regresi biaya pokok padi memiliki taraf nyata $\alpha$ adalah $1 \%$. Berdasarkan hasil uji t yang telah dilakukan diperoleh bahwa variabel bebas signifikan terhadap biaya pokok padi. Biaya pokok produksi padi organik lebih tinggi dibandingkan biaya pokok padi nonorganik dengan taraf nyata $\alpha$ sebesar $1 \%$. Tanpa membedakan musim tanam dan lokasi ratarata biaya pokok padi organik secara statistika ( $\alpha=1 \%$ ) lebih tinggi Rp1.592/kg dibandingkan dengan biaya pokok padi nonorganik. Berdasarkan Tabel 4 kemudian diperoleh model persamaan biaya pokok padi sebagai berikut:

$$
\widehat{Y}_{2}=3.149+1.5593 D_{1}-349 D_{5}+770 D_{4}
$$

Keterangan:

$\widehat{Y}_{2}=$ Biaya pokok produksi $(\mathrm{Rp} / \mathrm{kg})$

Berdasarkan pada persamaan biaya pokok yang telah diperoleh kemudian variabel bebas yang digunakan dimasukkan ke dalam persamaan tersebut. Maka diperoleh rata-rata biaya pokok usahatani padi yang dapat dilihat pada Tabel 5 .

Tabel 5. Rata-rata biaya pokok produksi padi (Rp/kg) di Kabupaten Pringsewu

\begin{tabular}{ccccc}
\hline Lokasi & Musim Tanam & Organik & Nonorganik & Rata-Rata \\
\hline \multirow{3}{*}{ Kec. Pringsewu } & MH & 5.163 & 3.570 & $\mathbf{4 . 3 6 7}$ \\
& MK & 5.512 & 3.920 & $\mathbf{4 . 7 1 6}$ \\
\cline { 2 - 5 } & Rata-Rata & $\mathbf{5 . 3 3 8}$ & $\mathbf{3 . 7 4 5}$ & $\mathbf{4 . 5 4 1}$ \\
\hline \multirow{3}{*}{ Kec. Pardasuka } & MH & 4.393 & 2.800 & $\mathbf{3 . 5 9 6}$ \\
& MK & 4.742 & 3.149 & $\mathbf{3 . 9 4 6}$ \\
\cline { 2 - 5 } & Rata-Rata & $\mathbf{4 . 5 6 7}$ & $\mathbf{2 . 9 7 5}$ & $\mathbf{3 . 7 7 1}$ \\
\hline Rata-Rata & & $\mathbf{4 . 9 5 2}$ & $\mathbf{3 . 3 6 0}$ & $\mathbf{4 . 1 5 6}$ \\
\hline
\end{tabular}

Tabel 5, menunjukkan bahwa rata-rata biaya pokok padi organik di Kabupaten Pringsewu lebih tinggi dibandingkan rata-rata biaya pokok padi nonorganik. Rata-rata biaya pokok padi 
organik di Kabupaten Pringsewu yaitu Rp4.952/kg sedangkan rata-rata biaya pokok padi nonorganik lebih rendah yaitu Rp3.360/kg. Presentase perbandingan biaya pokok produksi untuk usahatani padi organik yaitu sebesar $47,38 \%$. Biaya pokok yang dikeluarkan oleh petani pada usahatani padi organik lebih tinggi dibandingkan dengan biaya pokok usahatani padi nonorganik. Hal ini, dilatarbelakangi karena biaya total yang dikeluarkan oleh petani organik lebih tinggi dan produksi yang diperoleh petani padi organik justru lebih rendah dibandingkan usahatani padi nonorganik. Hal ini sejalan dengan penelitian (Nurjayanti, A., Effendi, I. dan Nurmayasari, 2016) yang mengatakan bahwa rata-rata biaya usahatani padi organik yang dikeluarkan oleh petani lebih besar dibandingkan dengan usahatani padi nonorganik.

Penggunaan input seperti penggunaan tenaga kerja dan penggunaan pupuk pada usahatani padi organik lebih banyak dibandingkan pada usahatani padi nonorganik. Penggunaan input tersebut yang membuat biaya total yang dikeluarkan oleh petani lebih besar dalam melakukan usahatani padi organik. Biaya nontunai yang dikeluarkan oleh petani organik justru lebih rendah dibandingkan dengan biaya nontunai yang dikeluarkan pada budidaya nonorganik. Hal ini dilatarbelakangi karena pada usahatani padi organik banyak penggunaan input yang diperoleh petani dari sumber daya alam yang tersedia di sekitar lingkungan petani, seperti benih yang digunakan berasal dari turunan hasil produksi padi organik pada musim sebelumnya. Begitu juga dengan pupuk organik dan pestisida nabati yang berasal dari bahan-bahan yang tersedia dilingkungan sekitar petani.

Biaya pokok padi organik adalah sebesar Rp4.952/kg sedangkan harga jual padi (GKG) organik yaitu Rp8.987/kg dengan harga jual padi organik yang masih lebih tinggi dibandingkan dengan biaya pokok produksi menunjukkan bahwa budidaya padi organik masih menguntungkan bagi petani dan masih layak untuk dibudidayakan. Konversi harga padi (GKG) organik diperoleh dari harga beras organik dibagi dengan harga beras nonorganik dikali dengan harga padi (GKG) nonorganik. Selain alasan kesehatan yang akan dirasakan manfaatnya oleh petani tetapi juga keuntungan yang diperoleh petani serta lahan petani yang baik atau tidak rusak akibat dari penggunaan pupuk kimia yang berlebihan. Hal ini, sejalan dengan penelitian Suhartini (2013) yang menyatakan bahwa kualitas lingkungan pada usahatani padi semi organik lebih baik daripada usahatani padi nonorganik.

\section{Analisis perbandingan pendapatan usahatani padi organik dan nonorganik di Kabupaten Pringsewu}

Hasil perbandingan padi organik terhadap pendapatan padi $(\mathrm{Rp} / \mathrm{ha})$ dapat dilihat pada Tabel 6. Tabel 6 terdapat dua analisis model regresi. Variabel bebas yang digunakan merupakan variabel yang sesuai dengan metodelogi dan variabel selain variabel organik merupakan variabel kontrol. Pada model 1 dapat dilihat bahwa ada salah satu variabel bebas yang tidak signifikan hadap produktivitas padi yaitu variabel musim tanam. Karena terdapat variabel bebas yang tidak signifikan. Kemudian dilakukan perubahan pengelompokkan dummy untuk variabel musim tanam. Perubahan yang dilakukan yaitu variabel musim tanam yang tadinya dibedakan berdasarkan musim tanam dan tahun musim tanam kemudian diubah menjadi hanya berdasarkan jenis musim tanam sehingga terdapat variabel bebas baru yaitu D5. Perubahan ini dilakukan karena hasil analisis yang dilakukan untuk model 1 variabel musim tanam terdapat hasil yang tidak signifikan. Setelah dilakukan perubahan pada musim tanam maka diperoleh hasil seperti model 2. Selanjutnya hasil pada model 2 ini yang akan digunakan untuk analisis. Perubahan pengelompokkan dummy dapat dilakukan jika telah memenuhi kriteria yang telah ditentukan, 
yaitu terdapat variabel bebas yang tidak signifikan terhadap variabel terikat dan terjadi kenaikan nilai adj R2 pada hasil analisis model selanjutnya.

Tabel 6. Model empiris analisis perbedaan pendapatan usahatani padi organik dengan padi nonorganik (Rp juta/ha)

\begin{tabular}{|c|c|c|c|c|c|c|c|}
\hline \multirow{2}{*}{$\begin{array}{c}\text { Variabel } \\
\text { bebas }\end{array}$} & \multirow{2}{*}{ Uraian } & \multicolumn{2}{|c|}{ Model 1} & & \multicolumn{3}{|c|}{ Model 2} \\
\hline & & Koefisien & P-value & & Koefisien & P-value & \\
\hline Intersep & & 12,60 & $1,83 \mathrm{E}-22$ & * & 12,60 & $7,38 \mathrm{E}-20$ & * \\
\hline D1 & Organik & 7,13 & $5,86 \mathrm{E}-11$ & $*$ & 7,13 & $4,90 \mathrm{E}-11$ & * \\
\hline D2(kontrol) & MT & 1,68 & $6,52 \mathrm{E}-01$ & & - & & \\
\hline D3(kontrol) & MT & $-4,47$ & $2,41 \mathrm{E}-01$ & & - & & \\
\hline D5(kontrol) & MT & - & & & 1,68 & $1,07 \mathrm{E}-01$ & * \\
\hline D4(kontrol) & Lokasi & $-4,47$ & $-4,56 \mathrm{E}+00$ & $*$ & $-4,47$ & $1,31 \mathrm{E}-05$ & $*$ \\
\hline $\mathrm{R} 2$ & & 0,4281 & & & 0,4270 & & \\
\hline $\begin{array}{l}\text { Adj. R2 } \\
\text { Ftest }\end{array}$ & & $\begin{array}{r}0,4059 \\
19,2747\end{array}$ & $7,33 \mathrm{E}-12$ & * & $\begin{array}{r}0,4104 \\
25,8292\end{array}$ & $1,45 \mathrm{E}-12$ & * \\
\hline Observasi & & 108 & & & $\begin{array}{r}108 \\
108\end{array}$ & & \\
\hline
\end{tabular}

Keterangan:

*: Signifikan

D5=1: Musim Hujan dan D5=0: Musim Kemarau

Model 2 diperoleh nilai R2 sebesar 0,4270, yang artinya bahwa sebesar 42,70\% pendapatan usahatani padi dapat dijelaskan oleh variabel padi organik, musim tanam dan lokasi, sedangkan sisanya sebesar 57,30 \% dapat dijelaskan oleh variabel lain yang tidak dimasukan ke dalam model. F-hitung pada hasil regresi pendapatan padi memiliki taraf nyata $\alpha$ adalah sebesar $1 \%$. Hasil uji t menunjukkan bahwa variabel bebas yang digunakan signifikan terhadap pendapatan padi. Pendapatan padi organik lebih tinggi dibandingkan pendapatan usahatani padi nonorganik dengan taraf nyata $\alpha$ sebesar $1 \%$. Artinya, dengan mengontrol variabel musim tanam dan lokasi. Pendapatan petani untuk padi organik rata-rata secara statistik ( $\alpha 1 \%)$ lebih tinggi Rp7,12 juta/ha dibandingkan dengan pendapatan padi nonorganik. Pada Tabel 6 diperoleh hasil model empiris, sehingga model persamaan yang diperoleh adalah sebagai berikut:

Y3 $=12,60+7,13 \mathrm{D} 1+1,68 \mathrm{D} 5-4,47 \mathrm{D} 4$

Variabel bebas yang digunakan dimasukkan ke dalam model persamaan yang diperoleh maka diperoleh rata-rata pendapatan padi yang dapat dilihat pada Tabel 7.

Tabel 7. Rata-rata pendapatan padi (Rp juta/ha) di Kabupaten Pringsewu

\begin{tabular}{ccccc}
\hline Lokasi & Musim & Organik & Nonorganik & Rata-Rata \\
\hline \multirow{3}{*}{ Kec. Pringsewu } & MH & 16,93 & 9,80 & $\mathbf{1 3 , 3 7}$ \\
& MK & 15,25 & 8,13 & $\mathbf{1 1 , 6 9}$ \\
\cline { 2 - 5 } & Rata-Rata & $\mathbf{1 6 , 0 9}$ & $\mathbf{8 , 9 6}$ & $\mathbf{1 2 , 5 3}$ \\
\hline \multirow{3}{*}{ Kec. Pardasuka } & MH & 21,40 & 14,27 & $\mathbf{1 7 , 8 4}$ \\
& MK & 19,73 & 12,60 & $\mathbf{1 6 , 1 6}$ \\
\cline { 2 - 5 } & Rata-Rata & $\mathbf{2 0 , 5 6}$ & $\mathbf{1 3 , 4 4}$ & $\mathbf{1 7 , 0 0}$ \\
\hline Rata-Rata & & $\mathbf{1 8 , 3 3}$ & $\mathbf{1 1 , 2 0}$ & $\mathbf{1 4 , 7 6}$ \\
\hline
\end{tabular}


Tabel 7 dapat dilihat bahwa rata-rata pendapatan usahatani padi organik lebih tinggi dibandingkan dengan pendapatan padi nonorganik. Rata-rata pendapatan padi orgainik yaitu sebesar Rp18,20 juta/ha. Rata-rata pendapatan padi nonorganik adalah sebesar Rp11,20 juta/ha. Presentase perbandingan pendapatan padi organik yaitu sebesar 38,90\% dibandingkan dengan pendapatan usahatani padi nonorganik. Hal ini sejalan dengan penelitian (Hasugian, J. K, Damayanti, Y, Nainggolan, 2016) yang mengatakan bahwa pendapatan usahatani pado organik lebih tinggi dibandingkan dengan pendapatan usahtani padi anorganik. Hal ini sejalan dengan penelitian (Pratama, D.I.A, Setiawan, B.M, Prasetyo, 2018)yang menyatakan bahwa pendapatan usahatani padi semi organik cenderung lebih besar daripada usahatani padi nonorganik.

Peningkatan pendapatan untuk usahatani padi organik terjadi karena harga jual padi organik lebih mahal dibandingkan dengan harga jual padi nonorganik di kabupaten pringsewu. Rata-rata harga jual padi (GKG) organik yaitu Rp8.987/kg sedangkan rata-rata harga jual padi (GKG) nonorganik adalah Rp5.482/kg. Hal ini yang membuat pendapatan petani padi organik lebih besar dibandingkan dengan pendpatan padi nonorganik, meskipun produksi yang dihasilkan pada usahatani padi organik lebih rendah dibandingkan dengan produksi padi nonoranik.

\section{KESIMPULAN}

Rata-rata produktivitas padi organik secara statistik ( $\alpha=1 \%$ ) lebih rendah yaitu sebesar 0,97 ton/ha dibandingkan dengan produktivitas padi nonorganik. Rata-rata biaya pokok padi organik secara statistika ( $\alpha$ $=1 \%$ ) lebih tinggi Rp1.592/kg dibandingkan dengan biaya pokok padi nonorganik. Pendapatan petani untuk padi organik rata-rata secara statistik ( $\alpha 1 \%$ ) lebih tinggi Rp7,12 juta/ha dibandingkan dengan pendapatan padi nonorganik

\section{DAFTAR PUSTAKA}

Cohen, L., Moarion, L. dan Marrioson, K. (2007) Research Methods In Education F. Sixth Edition. New York: Routledge.

Hadi, M., Dipokusumo, B., dan Zubair, M. (2019) 'Studi Perbandingan dan Pendapatan Usahatani Padi Organik dan Nonorganik di Desa Aik Dewa Keamatan Pringgasela Kabupaten Lombok Timur’, Jurnal Ilmiah Ilmu Pertanian Agroteksos, 29((1)), pp. 16-25.

Hasugian, J. K, Damayanti, Y, Nainggolan, S. (2016) 'Analisis Komperasi Usahatani Padi Organik Dan Nonorganik Di Kecamatan Sarolangun Kabupaten Sarolangun.’, Sosial Ekonomi Bisnis, 19(2).

Heryanto, Mahra, A., Sukayat, Y. and Supyandi, D. (2016) 'Model Perilaku Petani dalam Adopsi Sistem Usahatani Padi Organik : Paradoks Sosial-Ekonomi Lingkungan', Jurnal Sosiohumaniora, 18(2), pp. 159-165.

Maryowani, H. (2012) 'Pengembangan Pertanian Organik di Indonesia', Jurnal Forum Penelitian Pertanian Agro Ekononomi, 30(2), pp. 91-108.

Nurjayanti, A., Effendi, I. dan Nurmayasari, I. (2016) 'Pendapatan Dan Manfaat Usahatani Padi Organik Di Kabupaten Pringsewu.', JIIA, 4(2), pp. 126-133.

Pratama, D.I.A, Setiawan, B.M, Prasetyo, E. (2018) ‘Analisi Komparasi Usahatani Padi Semi Organik Dan Nonorganik Di Kecamatan Undaan Kabupaten Undaan’, Jurnal sosial ekonomi pertanian, 2(1), pp. $14-22$. 
Nurhidayati : Perbandingan Produktivitas, Biaya Pokok Produksi dan

Statistik, B. P. (2016) Sistem Petanian Organik. Jakarta: Standar Nasional Indonesia.

Sutarni, S. et al. (2019) 'Proses Pengambilan Keputusan Pembelian Sayuran Hidroponik Di Kota Bandar Lampung', Journal of Food System \& Agribusiness, 2(1), pp. 17-24. doi: 10.25181/jofsa.v2i1.1107.

Torchim, W. M. . (2020) Research Methods Knowledge Base. 